\title{
The Impact of Tourist Behaviors towards the Society Behavioral Change in Karimunjawa, Indonesia
}

\author{
Sandy Suharto Putro ${ }^{1}$, Nandi Kosmaryandi ${ }^{2}$, Tutut Sunarminto ${ }^{3}$ \\ 1 sandy azka@apps.ipb.ac.id \\ 1, 2,3 Institut Pertanian Bogor
}

$\begin{array}{ccc}\begin{array}{c}\text { Submitted } \\ \text { January 23, 2020 }\end{array} & \begin{array}{c}\text { Revised } \\ \text { June 18, 2020 }\end{array} & \begin{array}{c}\text { Accepted } \\ \text { June 25, 2020 }\end{array} \\ & \text { https://dx.doi.org/ 10.17509/jpis.v29i1.22961 } & \end{array}$

\section{ABSTRACT}

The increasing number of tourist visiting Taman Nasional Karimunjawa, Karimunjawa National Park, (herein referred to as TNKJ) has resulted in increased social interaction between tourists and local people. These conditions can affect the attitude of the community in Karimunjawa. The purpose of this study is to measure the influence of tourist behavior on changes in people's attitudes using a simple linear regression analysis method. The study was conducted in October-December 2019 with the research sample being the community of tourism service providers and non-tourism service providers. The hypothesis of this study is a negative influence of the perpetrators of tourists on the attitude of the people of TNKJ. The results of data analysis obtained (1) there is a significant influence of tourist behavior on the attitude of tourism service providers, as evidenced by the regression equation $Y=23,357+$ $0.457 \mathrm{X}$ and the coefficient of determination of $22.6 \%$. (2) there is no significant influence between the behavior of tourists on the attitude of the community not the provider of tourism services, as evidenced by the regression equation $Y=31,404+$ $0.168 \mathrm{X}$, but the $t$-test value is $1,947<1,994$ and the coefficient of determination is $5.3 \%$. Keywords: Social interactions, Tourist behavior, Community attitudes

\begin{abstract}
ABSTRAK
Meningkatnya jumlah kunjungan wisatawan ke Taman Nasional Karimunjawa mengakibatkan meningkatnya interaksi sosial antara wisatawan dengan masyarakat. Kondisi tersebut dapat berpengaruh terhadap sikap masyarakat di Karimunjawa. Tujuan penelitian ini adalah mengukur pengaruh perilaku wisatawan terhadap perubahan sikap masyarakat menggunakan metode analisis regresi linear sederhana. Penelitian dilaksanakan pada bulan Oktober-Desember 2019 dengan sampel penelitian adalah masyarakat penyedia jasa wisata dan masyarakat bukan penyedia jasa wisata. Hipotesis penelitian ini adalah terdapat pengaruh negatif pelaku wisatawan terhadap sikap masyarakat Karimunjawa. Hasil analisis data diperoleh (1) terdapat pengaruh signifikan perilaku wisatawan terhadap sikap masyarakat penyedia jasa wisata, dibuktikan dengan persamaan regresi $Y=23.357+0.457 \mathrm{X}$ dan nilai koefisien determinasi sebesar $22.6 \%$. (2) tidak terdapat pengaruh signifikan antara perilaku wisatawan terhadap sikap masyarakat bukan penyedia jasa wisata, dibuktikan dengan persamaan regresi $\mathrm{Y}=31.404+0.168 \mathrm{X}$, namun besaran $\mathrm{t}$ hitung $1.947<1.994$ dan nilai koefisien determinasi sebesar 5.3\%.

Kata Kunci: Interaksi sosial, Perilaku wisatawan, Sikap masyarakat
\end{abstract}

\section{INTRODUCTION}

Kariwunjawa island is one of the Indonesian national parks located in
Jepara, East Java, spreading on a land as wide as 111,625 hectares [1]. Some of the potentials of Karimunjawa National 
Park, herein to be referred as TNKS which stands for Taman Nasional Karimunjawa, are its biodiversity, the natural condition of its lowland tropical rain forest, its white sand beach with its coral reefs around the beach, and its rich society culture to be developed as ecotourism [2]. In terms of the number of visiting tourists, the ecotourism in TNKJ has been rapidly developing. According to Indonesian Central Bureau of Statistics (BPS), in 2019 the number of visiting tourists to the site recorded was as many as 129,679 marking an increase by $12.7 \%$ compared to that in 2018 .

The increasing number of tourists visiting TNKJ will likely to also enhance the interaction between the tourists and local people [3]. The interaction between the local people and the tourists does influence the socio-cultural conditions as well as the experience quality of the tourists acquired from the direct interaction with the local people of TNKJ [4].

Community interactions with tourists can affect the lives of tourists and the community both socially and culturally, causing a positive and negative impact on changes in social and cultural values, as well as changes in habits and lifestyles [5].

The existence of the development of tourism, is one of the deep contributing factors, these changes can be inversely proportional to the social system which also experiences changes that can be felt by the people. [6].

The direct involvement of some Karimunjawa people in ecotourism activities will increase direct interaction between the community and tourists and cause influence on the sociocultural conditions [3]. Tourist behavior can have a positive and negative impact on people's attitudes. The negative impacts that occur in Karimunjawa are the consumption of alcohol and riots between citizens, youth fights, conflicts with the TNKJ managers, fraud and theft, while the impact of ecotourism activities on the environment include a decrease in water quality, increased land opening, increased waste and pollution [7]. The purpose of this study is to measure the influence of tourist behavior on changes in Karimunjawa community attitudes related to environmental and socio-cultural conditions.

\section{LITERATURE REVIEW}

\section{Social Interactions}

Social interaction is a complex phenomenon that involves different dimensions of verbal and nonverbal behavior and different contexts [8]. As social beings, humans need interaction with other people [9]. The cause of social interaction is social contact, and communication where someone gives meaning to other people's behavior and feelings to be conveyed. The forms of social interaction are cooperation, competition, accommodation and conflict. Exchange of information about experiences as a product of social interaction has clear implications for providing products or experiences that satisfy their needs [10].

\section{Attitude}

Attitude can be defined as a tendency to act, as well as feelings, beliefs and values held [11]. Attitude is a very important factor in influencing human behavior based on personal opinions formed through personal life experiences and education [12]. Attitudes can have implications for actions according to one's circumstances. 


\section{Tourist Behavior}

Tourist behavior is the process and activity involved when people search, choose, use, evaluate, and dispose of products and services to satisfy their needs and desires [13]. Tourist behavior is a context that can be observed from the past although not always in a clear manner [14]. Tourist behavior is a psychological response that arises in the form of individual actions in an effort to obtain and use products [15]. Factors that influence tourist behavior are cultural factors, social factors, personal factors, and psychological factors [16], [17].

\section{RESEARCH METHODS}

\section{Time and Location}

The study was conducted in October-December 2019. The research location was in Karimunjawa Village, Karimunjawa District, Jepara Regency, Indonesia.

\section{Sample}

This study used descriptive qualitative method. Sampling of this study uses an acidental sampling method which is a sampling technique that is not guided by clear characteristics of the participants that are available and easily contacted and deemed suitable as data sources [18], [19]. The sample was divided into 2 groups, namely community service providers and non-tour service providers. The difficulty in determining the population is due to the absence of exact data regarding the number of community service providers. The sample of 100 respondents from a population of 5,000 has the same estimation accuracy as a population of 200 million. So that the sample size in this study were 200 respondents (100 community service providers and 100 non-tourism service providers).

\section{Data Analysis Procedure}

Data analysis used simple linear regression analysis to measure the effect of tourist behavior on the attitude of the people of Karimunjawa from the variables determined by calculating the scoring of each question instrument using a Likert scale. These variables are tested for validity and reliability to measure the accuracy and consistency of a measuring instrument in making measurements

Tabel 1. Matrix of dependent and independent variables

\begin{tabular}{ll}
\hline \multicolumn{1}{c}{ Variable } & \multicolumn{1}{c}{ Indicator } \\
\hline Dependent variable community attitudes & 1. Social economy \\
Independent variable Tourist behavior & 2. Social culture \\
& 3. Environment \\
1. How to talk \\
2. How to dress \\
3. Security and order \\
4. Customs and culture \\
5. Economy \\
6. Environment
\end{tabular}

Source: Data processing

1) Normality Test

This test aims to determine the distribution of data on each variable that will be used in research normally distributed or not. The normality test in this study uses the Kolmogorov-Smirnov test with the assumption that:

a) Data are normally distributed, if the value of sig (significance) > 0.05; 
b) Data are not normally distributed, if the value of sig (significance) $<0.05$.

2) Linearity Test

This test aims to find out a significantly linear relationship between variables. A good correlation should have a linear relationship between variables. This test uses a compare means method that will produce ANOVA tables with decision making, if the value of deviation from linearity sig. > 0.05, then there is a significant linear relationship between the independent variable and the dependent variable;

\section{3) Heteroscedasticity Test}

This test aims to test whether in the regression model a variant inequality occurs from the residual value of one observation to another. Regression models should not occur symptoms of heteroscedasticity How to test it using the Glejser test, which is regressing the independent variable to the absolute residual value. The basis for decision making in the heteroscedasticity test is if the sig value $>0.05$, then there is no symptom of heteroscedasticity. If there is a symptom of heteroscedasticity, solve it by transforming the linear regression equation into logistic regression.

\section{4) Simple Linear Regression Analysis}

It is a statistical method that observes the relationship between the dependent variable $\mathrm{Y}$ and $a$ set of independent variables $\mathrm{X}_{1}, \ldots, \mathrm{Xp}$, which aims to predict the value of $Y$ for a given value of $X$ and simple linear regression is a regression model that has only one independent variable $\mathrm{X}$. Regression analysis has several uses, one of which is to predict the dependent variable $\mathrm{Y}$. The equation for a simple linear regression model is as follows:

$$
\boldsymbol{Y}=\boldsymbol{a}+\boldsymbol{b X}
$$

Information:

$\mathrm{Y}=$ Variable due (dependent)

$\mathrm{X}=$ Cause variable (independent)

$\mathrm{a}=\mathrm{a}$ constant

$\mathrm{b}=$ regression coefficient

5) $T$ test

T test is used to test the truth or falseness of the null hypothesis which states that there is a partial influence or not given a variable. After conducting a factor analysis of each variable, it will produce a t test and significance level using Analysis of Variance (ANOVA). ANOVA is a method for testing the relationship between independent variables and dependent variables. The research hypothesis is:

$\mathrm{Ho}:=0 \quad$ (there is no negative influence of tourist behavior on the changing attitude of the people of Karimunjawa)

$\mathrm{H} 1: \neq 0 \quad$ (there is a negative influence of tourist behavior on the changing attitude of the Karimunjawa community)

6) Correlation Coefficient Test (R) and Determination ( $\mathrm{R} 2$ )

Correlation coefficient test is a test used to determine whether there is a relationship between the independent variable and the dependent variable. The magnitude of the correlation coefficient is said to be good if it approaches the value of -1 to 1 , but if the value of the correlation coefficient is 0 or close to 0 then the relationship between variables is weak or there is no relationship. The correlation coefficient test uses Pearson, with decision making if the value of sig $<0.05$ then there is a correlation between the independent variable and the dependent variable.

The coefficient of determination test aims to determine the amount of influence of independent variables on 
the dependent variable. The coefficient of determination is obtained from the squaring of the correlation coefficient with a range of values from 0 to 1 , if $R_{2}$ is negative (-) then there is no influence between variables.

\section{RESULTS AND DISCUSSION}

\section{Tourist Characteristics}

Karimunjawa National Park is a tourist destination for tourists who come from Java, judging from the tourist origin profile based on the results of the study presented in Appendix 1 showing that tourists from Central Java dominate tourists visiting the TNKJ. But tourists from other regions such as Jakarta and West Java visited quite a lot of TNKJ. The small number of tourist arrivals from outside of Java is caused by the distance to TNKJ which takes quite a lot of time and frequency of crossings and flights, so that tourists cannot make a visit in just one day. Most tourists visit TNKJ on holidays or weekends.

Tourists in TNKJ come from various age groups with a predominance of 21-30 years of age 64 people (32\%) and college education level of 91 people $(45.5 \%)$, this shows that tourists in the TNKJ are dominated by young age. Types of tourist jobs are mostly private employees with a total of 74 people (37\%) with an average cost of Rp. 250,000 - Rp. 500,000 .- / person / visit. Most of the first time tourists make a visit to TNKJ a number of 149 people (74.5\%) for reasons of various visits such as being curious about the beauty of the Karimunjawa National Park and trying out marine tourism destinations. Group tour is a form of visit that is mostly done by tourists as many as 76 people (38\%) with a length of visit of 3 days (58\%) because there are many tour and travel agents that sell group tour packages to
TNKJ at a lower cost compared to individuals. In line with the accommodation used is dominated by homestays $(84 \%)$ because prices are cheaper than hotels.

The large number of tourism potentials in the Karimunjawa National Park, makes tourists have many choices for activities. But many tourists who come to TNKJ have purchased tour packages offered by service providers, so that scheduled tourist destinations such as snorkeling (183 people), relaxing on the beach (174 people), and tracking mangroves (39 people). In addition to scheduled tourist destinations, tourists can do activities outside the tour packages such as religious tourism (Pilgrimage of the Kyai Nyamplung Tomb) and cultural tourism (Bukit Joko Tuo, Bugis Village) but the number of visits is limited because tourists are more interested in marine tourism types.

\section{Simple Linear Regression Analysis}

1) Normality Test

Based on the results of the Kolmogorov-Smirnov normality test using the IBM SPSS 23 software for the respondents of the travel service provider community, the value of sig is obtained. of $0.200>0.05$ and non-tourist service providers obtained sig values. Is $0.200>0.05$. So that in accordance with the assumptions of decision making in the Kolmogorov-Smirnov normality test, it can be concluded that the data of the respondent community service providers are normally distributed and can be continued in the next requirements test.

\section{2) Heteroscedasticity Test}

Testing heteroscedasticity in this study showed the value of sig. for community tourism service provider 
respondents is $0.851>0.05$ and community respondent is not a tourism service provider so that $0.057>0.050$. So that in accordance with the assumptions that have been set, all independent variables showed no symptoms of heteroscedasticity.

\section{3) Simple Linear Regression}

Based on the results of calculations using IBM SPSS 23 software, the results obtained as presented in table 2 obtained constant values (a) and regression coefficient values (b). Constants in simple linear regression mean the intersection of the regression line with the $Y$ axis, with fixed and irreversible value properties. While the regression coefficient is the value of the slope or direction of the regression line which states the change in the value of $Y$ due to changes in the value of $X$.

Respondents in the tourism service provider community obtained a value of 23,357, this figure implies that if there is no value (0) of the independent variable (tourist behavior) then the value of community attitudes is 23,357 . Regression coefficient (b) of 0.457 , this number implies that every $1 \%$ addition of the independent variable (tourist behavior), the attitude of the community will increase by 0.457 . So that it can be seen the regression equation from the respondent of the tourism service provider community is $Y$ $=23,357+0.457 \mathrm{X}$, meaning that the behavior of tourists has a positive or direct effect on the attitudes of the tourism service provider community.

Tabel 2. Simple Regression Analysis Results

\begin{tabular}{lcccc}
\hline \multicolumn{1}{c}{ Respondent } & (a) & (b) & t count & t table \\
\hline Community service providers & 23.357 & 0.457 & 4.462 & 1.994 \\
The community is not a tourist service provider & 31.404 & 0.168 & 1.947 & 1.994 \\
\hline
\end{tabular}

Source: Data processing

The results of a simple regression analysis for non-tourism service community respondents obtained a constant value (a) of 31,404, meaning that if there is no value (0) of the independent variable (tourist behavior) then the value of community attitudes is 31,404. Regression coefficient (b) of 0.168 , this number implies that every $1 \%$ addition of the independent variable (tourist behavior), people's attitudes will increase by 0.168 . So that it can be seen the regression equation from the respondent of the community tourism service provider is $Y=31.404+0.168 \mathrm{X}$, meaning that the behavior of tourists has a positive or direct effect on people's attitudes.

\section{4) T test}

Hypothesis testing uses significance test with $t$ test, where if $t_{\text {count }}>t_{\text {table }}$ then reject $\mathrm{Ho}$, whereas if tcount <ttable then accept Ho with a probability of 0.050 . The research hypothesis is:

Ho : = o (there is no significant negative effect of tourist behavior on changes in the attitude of the people of Karimunjawa)

$\mathrm{H} 1: \neq 0$ (there is a significant negative effect of tourist behavior on changes in the attitude of the people of Karimunjawa)

Based on Table 2, it is known that the tcount for the community of tourism service providers is 2,300>1,994 ( $t_{\text {table }}$ ) and the significance value is 0.024 $<0.050$, in accordance with the research 
hypothesis of rejecting $\mathrm{HO}$ and accepting $\mathrm{H}_{1}$. This means that there is a significant negative influence of tourist behavior on changes in community attitudes in Karimunjawa.

For non-tourism service providers, a tcount of 1,947<1,994 (ttable) was obtained and a significance value of $0.056>0.050$, in accordance with the research hypothesis of accepting Ho and rejecting $\mathrm{H} 1$. This means that there is no significant negative effect of tourist behavior on changes in community attitudes in Karimunjawa.

\section{5) Correlation Coefficient Test (R) and} Determination $\left(R^{2}\right)$

The results of the correlation coefficient test ( $R$ ) found that the correlation coefficient value of the community of tourism service providers has a moderate correlation with a value of 0.476 and a sig value of $0.00<0.050$. Whereas the respondent of the community not the tourism service provider did not have a correlation, because the sig value was $0.056>0.050$ even though the $R$ value was 0.230 .

The results of the coefficient of determination test showed a value of
0.226 or $22.6 \%$ for the tourism service provider community and 0.053 or $5.3 \%$ for the non-tourist service provider community. It is concluded that there is a negative influence, although weak from the behavior of tourists towards the attitude of the community of tourism service providers by $22.6 \%$ and the remaining $77.4 \%$ is influenced by other variables. The weak influence of tourist behavior on the attitude of tourism service providers is presumably because the majority of tourists come from Java, which has the same cultural values and norms as the Karimunjawa community.

For non-tourist service providers, tourist behavior has a very weak influence or almost no effect on people's attitudes, which is $5.3 \%$. This is allegedly because the community is not a service provider rarely interact directly with tourists. But it will be a threat to the change in attitude of the community not the provider of tourism services even though it is not directly affected by tourist behavior, because interactions that occur between people and do not filter the information received can even be exaggerated.

Tabel 3. The results of the correlation coefficient $(R)$ test and determination $\left(R^{2}\right)$

\begin{tabular}{lllll}
\hline \multicolumn{1}{c}{ Respondents } & \multicolumn{1}{c}{$\mathbf{R}$} & $\mathbf{R}^{2}$ & \multicolumn{1}{c}{ sig. } & \multicolumn{1}{c}{ Information } \\
\hline $\begin{array}{l}\text { Community service } \\
\text { providers }\end{array}$ & 0.476 & 0.226 & 0.000 & $\begin{array}{l}\text { Moderate correlation } \\
\text { and weak influence }\end{array}$ \\
$\begin{array}{l}\text { The community is not a } \\
\text { tourist service provider }\end{array}$ & 0.230 & 0.053 & 0.056 & $\begin{array}{l}\text { There is no correlation } \\
\text { and the influence is very } \\
\text { weak }\end{array}$ \\
\hline
\end{tabular}

Sumber: pengolahan data

\section{CONCLUSION}

The results of a simple regression analysis related to the influence of tourist behavior on the attitudes of tourism service providers in Karimunjawa obtained a regression equation $Y=31,595+0.244 X$, where tourist behavior is positive and has an influence. So based on the hypothesis test there is a negative influence of tourist behavior on the attitude of the community of tourism service providers by $22.6 \%$. Whereas for non-tourism service providers, the regression equation $\mathrm{Y}=31.404+0.168 \mathrm{X}$ is obtained, but the $t$-count is $1.947<1.994$. Based on 
hypothesis testing, there is no negative influence of tourist behavior on community attitudes.

The magnitude of changes in community attitudes is not large, because tourists are still dominated by tourists from Java who have almost the same culture and customs, but it will be different if tourists come from areas that have different cultures from the Karimunjawa community and cultural values and customs are not preserved. by the Karimunjawa community. The influence of tourist behavior has an impact on changes in community attitudes related to the existence of ecotourism activities in Karimunjawa. The impact is in the form of changes in social, cultural, economic and environmental aspects. Changes in attitude can pose a threat to the cultural conditions and customs inherent in the Karimunjawa community.

\section{RECOMMENDATION}

Measuring changes in community attitudes is recommended using other indicators such as technological development to anticipate the occurrence of greater negative influences. Preservation of local cultural values in addition to being a tourist attraction for tourists, as well as a medium to filter out the negative influences brought by tourists.

\section{References}

[1] H. Susanto, I. Taufiqurrahman, and S. B. Van Balen, "Waders of Karimunjawa national park, Central java, Indonesia," Stilt, vol. 66, no. 66, pp. 1-9, 2014.

[2] A. N. Laksono and Mussadun, "Dampak Aktivitas Ekowisata Di Pulau Karimunjawa Berdasarkan Persepsi Masyarakat," Tek. Perenc. Wil. Kota, vol. 3, no. 2, pp.
262-273, 2014.

[3] Thelisa, M. Budiarsa, and Widiastuti, "Pengaruh Pariwisata Terhadap Kondisi Sosial Budaya Masyarakat Karimunjawa, Jawa Tengah," J. Manaj. Pariwisata, vol. 4, no. 2, 2018.

[4] P. A. Prayogi, "Dampak Perkembangan Pariwisata Di Objek Wisata Penglipuran," J. Perhotelan Dan Pariwisata, vol. 1, no. 1, pp. 64-79, 2011.

[5] S. S. Oktaviyanti, "Dampak Sosial Budaya Interaksi Wisatawan Dengan Masyarakat Lokal di Kawasan Sosrowijayan," Dampak Sos. Budaya Interak. Wisatawan Dengan Masy. Lokal Di Kaw. Sosrowijayan, vol. 5, no. 3, pp. 201-208, 2013, doi: 10.22146/jnp.6693.

[6] R. Fahlevy and R. T. Saputri, "Pariwisata Terhadap Perekonomian Masyarakat Desa Kurau Barat Kecamatan Koba," J. Pendidik. Ilmu Sos., vol. 29, no. 1, pp. 42-48, 2019.

[7] A. Widyawati, "Akar Konflik Dalam Masyarakat Multikultural Di Karimunjawa," Yust. J. Huk., vol. 93, no. 3, pp. 602-616, 2015, doi: 10.20961/yustisia.v93io.3688.

[8] H. De Jaegher, E. Di Paolo, and S. Gallagher, "Can social interaction constitute social cognition?," Trends Cogn. Sci., vol. 14, no. 10, pp. 441-447, 2010, doi: 10.1016/j.tics.2010.06.009.

[9] M. S. Satya, "Strategi Masyarakat Etnis Tionghoa Dan Melayu Bangka Dalam Membangun Interaksi Sosial Untuk Memperkuat Kesatuan Bangsa," J. Pendidik. Ilmu Sos., vol. 25, no. 1, p. 110, 2016, doi: 10.17509/jpis.v25i1.3667.

[10] L. Murphy, "Exploring social 
interactions of backpackers," Ann. Tour. Res., vol. 28, no. 1, pp. 50-67, Jan. 2001, doi: 10.1016/S0160-7383(00)00003-7.

[11] J. Osborne, S. Simon, and S. Collins, "Attitudes towards science: A review of the literature and its implications," Int. J. Sci. Educ., vol. 25, no. 9, pp. 10491079, 2003, doi: $10.1080 / 0950069032000032199$.

[12] E. Hacieminoglu, "Elementary school students' attitude toward science and related variables," Int. J. Environ. Sci. Educ., vol. 11, no. 2, pp. 35-52, 2016, doi: 10.12973/ijese.2016.288a.

[13] M. A. Morissan, Periklanan Komunikasi Pemasaran Terpadu. Jakarta: Prenadamedia Grup, 2010.

[14] F. Kock, A. Josiassen, and A. G. Assaf, "On the origin of tourist behavior," Ann. Tour. Res., vol. 73, no. March, pp. 180-183, 2018, doi: 10.1016/j.annals.2018.04.002.
[15] H. Ali, Marketing. Yogyakarta: Media Pressindo, 2009.

[16] L. Moutinho, "Consumer Behaviour in Tourism," Eur. J. Mark., vol. 21, no. 10, pp. 5-44, Oct. 1987, doi: 10.1108/EUMoo00000004718.

[17] H. San Martín and I. A. Rodríguez del Bosque, "Exploring the cognitive-affective nature of destination image and the role of psychological factors in its formation," Tour. Manag., vol. 29, no. 2, pp. 263-277, 2008, doi: 10.1016/j.tourman.2007.03.012.

[18] I. Etikan, "Sampling and Sampling Methods," Biometrics Biostat. Int. J., vol. 5, no. 6, pp. 5-7, 2017, doi: 10.15406/bbij.2017.05.00149.

[19] A. Koerber and L. McMichael, "Qualitative sampling methods: A primer for technical communicators," J. Bus. Tech. Commun., vol. 22, no. 4, pp. 454473, 2008, doi: $10.1177 / 1050651908320362$. 